\title{
Inflammatory biomarkers in type 2 diabetic patients: effect of glycemic control and impact of Idl subfraction phenotype
}

Irene Vinagre ${ }^{1,2^{*}}$, José Luis Sánchez-Quesada ${ }^{3}$, Juan Sánchez-Hernández ${ }^{4}$, David Santos ${ }^{3,4}$, Jordi Ordoñez-Llanos ${ }^{3,5,6}$, Alberto De Leiva ${ }^{1,7}$ and Antonio Pérez ${ }^{1,4^{*}}$

\begin{abstract}
Background: Type 2 diabetes mellitus (T2D) is associated with higher cardiovascular risk partly related to an increase in inflammatory parameters. The aim of this study was to determine the association of inflammatory biomarkers with low-density lipoprotein (LDL) subfraction phenotype and glycemic control in subjects with T2D and poor glycemic control.

Methods: A cross-sectional study was performed comparing 122 subjects with T2D ( $59 \pm 11$ years old, body mass index $30.2 \pm 5.6 \mathrm{~kg} / \mathrm{m} 2$ ) with 54 control subjects. Patients with T2D were classified according to their LDL subfraction phenotype and inflammatory biomarkers (C-reactive protein, Interleukin-6, Interleukin-8, Transforming growth factor $\beta_{1}$, Monocyte chemotactic protein 1, Leptin, Adiponectin) were evaluated according to the degree of glycemic control, LDL phenotype and other clinical characteristics. Forty-two subjects with T2D were studied before and after 3 months of improving glycemic control by different strategies.

Results: Patients with T2D had higher C-reactive protein (CRP) and monocyte chemotactic protein-1 (MCP1) levels and lower adiponectin concentration, compared to controls. T2D subjects with body mass index $\geq 30 \mathrm{~kg} / \mathrm{m} 2 \mathrm{had}$ higher CRP levels $(5.2 \pm 4.8 \mathrm{mg} / \mathrm{l}$ vs $3.7 \pm 4.3 \mathrm{mg} / \mathrm{l} ; \mathrm{p}<0.05)$. The presence of $\mathrm{LDL}$ phenotype $B$ was related to higher levels of transforming growth factor- $\beta_{1}\left(\right.$ TGF- $\left.\beta_{1}\right)(53.92 \pm 52.82 \mathrm{ng} / \mathrm{l}$ vs $31.35 \pm 33.74 \mathrm{ng} / \mathrm{l} ; \mathrm{p}<0.05)$ and lower levels of adiponectin $(3663 \pm 3044 \mathrm{ng} / \mathrm{l}$ vs $2723 \pm 1776 \mathrm{ng} / \mathrm{l} ; \mathrm{p}<0.05)$. The reduction of HbA1c from $9.5 \pm 1.8 \%$ at baseline to $7.4 \pm 0.8 \%$ was associated with a significant reduction of TGF- $\beta_{1}(41.86 \pm 32.84 \mathrm{ng} / \mathrm{l} \mathrm{vs} 26.64 \pm 26.91 \mathrm{ng} / \mathrm{l}$; $p=0.02$ ).

Conclusions: Subjects with T2D, especially those with LDL phenotype B and obesity, have higher levels of inflammatory biomarkers. Improvement of glycemic control reduces TGF- $\beta_{1}$ levels, which may contribute partly to its renoprotective role.
\end{abstract}

Keywords: Inflammatory biomarkers, C-reactive protein, Adiponectin, Monocyte chemotactic protein-1, Transforming growth factor- $\beta_{1}$, Tumor growth factor $\beta_{1}$, Type 2 diabetes, LDL phenotype, Atherogenic dyslipidemia

\footnotetext{
* Correspondence: ivinagre@clinic.ub.es; aperez@santpau.cat

'Endocrinology and Nutrition Department, Hospital de la Santa Creu i Sant

Pau, C/ Mas Casanovas 90, Barcelona 08025, Spain

${ }^{4}$ CIBER of Diabetes and Metabolic Diseases (CIBERDEM), Barcelona, Spain

Full list of author information is available at the end of the article
} 


\section{Background}

Type 2 diabetes mellitus is one of the most common diseases in occidental society and it is associated with a high cardiovascular risk, not only due to the classical factors but also to a chronic low-grade inflammation [1]. In this sense, epidemiological studies have demonstrated an increase in plasma levels of inflammatory markers such as CRP, IL-6 and TNF- $\alpha$ in patients with metabolic syndrome and also in those with clinically overt T2D $[2,3]$. Other molecules such as the transforming growth factor (or tumor growth factor) $\beta_{1}[4]$, MCP1 [5,6] or LP-PLA2 [7] also present increased concentrations in T2D subjects.

A genetic predisposition associated to excessive caloric intake and a lack of physical excercise can lead to obesity and central adiposity. Then, this may result in adipose tissue dysfunction, macrophage infiltration and a greater release of cytokines such as IL-6 and TNF- $\alpha$. Chronically elevated levels of these biomarkers promote insulinresistance in skeletal muscle and endothelial dysfunction, as well as liberation of CRP from the liver [8]. Moreover, hyperglycaemia also induces IL- 6 production from endothelium and macrophages, which might worsen insulin liberation and signaling cascades. This suggests that improving glycemic control might reduce the inflammatory response supporting the link between inflammation and glucose metabolic disturbance.

On the other hand, previous studies have demonstrated a significant correlation between CRP levels and features of the metabolic syndrome, including adiposity, hyperinsulinemia, insulin resistance, hypertriglyceridemia and low HDLc [9-11]. Interestingly, lifestyle and pharmacological interventions in T2D such as statins, angiotensin receptor blockers and glitazones have demonstrated a beneficial effect on markers of inflammation [12-15]. However, the correlation between inflammatory markers and glycemic control is significant in some studies $[16,17]$ but not in others [18], and available information about the effect of an improvement of glycemic control on inflammatory markers is very scarce $[19,20]$. Moreover, the impact of the presence of the atherogenic LDL subfraction phenotype, very common in T2D, on inflammatory markers has not been previously analyzed in these subjects.

Therefore, the aim of this study was to determine the association of inflammatory biomarkers with glycemic control and LDL subfraction phenotype.

\section{Methods}

\section{Patients}

This report includes a cross-sectional study with 122 consecutive poor controlled T2D patients who attended an out-patient diabetic clinic between 2007 and 2008 to optimize glycemic control. Patients were selected on the basis of poor glycemic control (HbA1C $>8.5 \%)$. As a control group, we selected 54 normoglycemic and normolipemic healthy subjects, without chronic pharmacological medication. This cohort of patients had been studied previously [21,22]. Anthropometrical and clinical characteristics of patients and controls, which have been reported elsewhere [22], are shown in Table 1. Briefly, previous pharmacological hypoglycemic treatment consisted of diet only (22\%), oral agents $(21.1 \%)$, insulin plus oral agents (29.4\%) and insulin alone (27.5\%). Pharmacological hypolipidemic treatment included statins (25.4\%), fibrates $(4.1 \%)$, statins plus fibrates $(2.5 \%)$ and statins plus ezetimibe (1.6\%). Patients with acute or chronic infections, active inflammatory disease or treatment with anti-inflammatory drugs were excluded. Subjects with CRP higher than $20 \mathrm{mg} / \mathrm{L}$ were also excluded from the study. A longitudinal study was also performed in a subgroup of 42 subjects with T2D and poor glycemic control, defined as $\mathrm{HbA} 1 \mathrm{c}>8.5 \%$, who were recruited consecutively from the diabetes clinic [21]. All patients were evaluated before and after 3 months of glycemic optimization in a clinical practice setting with different strategies, which included lifestyle counseling and intensification of pharmacological hypoglycemic therapy with oral agents (metformin or metformin plus sulphonylurea) in 6 patients, insulin therapy in 31 patients or both (insulin plus metformin or insulin plus metformin and sulphonylurea) in 5 patients [21]. Lipid-lowering and antihypertensive therapy was unchanged.

The study was performed in accordance with the principles of the Declaration of Helsinki and was approved by the Hospital's ethics committee. All patients and controls signed informed consent.

\section{Laboratory analysis}

Blood specimens were obtained after overnight fasting. HbA1c was measured by ion-exchange high-performance liquid chromatography (HPLC; variant II, Bio-Rad) with a reference range of 4.6-5.8\%. LDL subfraction phenotype was determined by measuring LDL size, determined by non-denaturing polyacrylamide gradient (2-16\%) gel electrophoresis, as described [23]. LDL subfraction phenotype $B$ was defined by a predominant LDL diameter lower than $25.5 \mathrm{~nm}$, while phenotype A subjects had a LDL diameter higher than $25.5 \mathrm{~nm}$. C-reactive protein was measured by a highly-sensitive commercial method (hsCRP, Roche Diagnostics) in Hitachi 917 autoanalyzer. Interleukin 6, IL-8, MCP1, TGF- $\beta_{1}$, leptin and adiponectin were measured by ELISA from Bender Medsystems (IL-6, IL-8, MCP1 and TGF- $\beta_{1}$ ), or R\&D (leptin and adiponectin).

\section{Statistical analysis}

Statistical analysis was performed using SPSS version 15.0 (SPSS Inc.). Before statistical analysis, normal 
Table 1 Anthropometric and clinical characteristics of control subjects and patients with type 2 diabetes at baseline

\begin{tabular}{lcc}
\hline & $\begin{array}{c}\text { Control group } \\
(\mathbf{N}=\mathbf{5 4})\end{array}$ & $\begin{array}{c}\text { Type 2 diabetes } \\
(\mathbf{N}=\mathbf{1 2 2})\end{array}$ \\
\hline Age (years) & $56 \pm 14$ & $59 \pm 11$ \\
Diabetes duration (years) & - & $10.61 \pm 10.26$ \\
Chronic complications: & - & \\
$\quad$ • Retinopathy (\%) & & 29.7 \\
$\quad$ - Nephropathy (\%) & & 32.4 \\
$\quad$ • Coronary Heart Disease (\%) & & 9.9 \\
Antihypertensive medication (\%) & - & 67.9 \\
Cholesterol lowering medication (\%) & - & 33.6 \\
Weight (kg) & $69.3 \pm 11.4$ & $82.1 \pm 18.8^{*}$ \\
Waist (cm) & $92 \pm 11$ & $105 \pm 14^{*}$ \\
Body mass index (Kg/m2) & $25.9 \pm 3.5$ & $30.2 \pm 5.6^{*}$ \\
\hline
\end{tabular}

Data are expressed mean \pm SD

${ }^{a}$ Nephropathy defined as impaired renal function (eGFR $<60 \mathrm{ml} / \mathrm{minut}$ ) or 2 or more urinary determinations of microalbuminuria $\geq 20 \mathrm{mg} / \mathrm{l}$ or $\geq 30 \mathrm{mg} / \mathrm{g}$ of creatinine.

*Statistically significant $(p<0.05)$

distribution and homogeneity of the variances were tested using Kolmogorov-Smirnov and Levène tests, respectively. Data that were not normally distributed were logarithmically transformed before analysis. Groups were compared using Student's unpaired t test for parameters with normal distribution or Mann-Whitney test for parameters with non-normal distribution. The effect of glycemic optimization was analyzed using Student's paired $t$ test for parameters with normal distribution or Wilcoxon test for parameters with non-normal distribution. Correlations between parameters were analyzed using the Pearson $\mathrm{R}$ test for variables with normal distribution and the Spearman test for variables with non-normal distribution. Data are expressed as mean \pm standard desviation. $\mathrm{P}<0.05$ was considered significant.

\section{Results}

Table 2 shows inflammation parameters of patients with T2D and controls. T2D subjects had higher CRP and MCP1 levels, and lower adiponectin concentrations than controls. One third $(n=44)$ of patients with T2D presented phenotype $B$, in contrast to the control group in which all subjects $(n=54)$ had phenotype A. Compared to T2D patients with LDL phenotype A, subjects with LDL phenotype $\mathrm{B}$ had higher concentrations of TGF- $\beta_{1}$ $(53.92 \pm 52.82 \mathrm{ng} / \mathrm{l}$ vs $31.35 \pm 33.74 \mathrm{ng} / \mathrm{l} ; \mathrm{p}<0.05)$ and lower of adiponectin $(3663 \pm 3044 \mathrm{ng} / \mathrm{l}$ vs $2723 \pm$ $1776 \mathrm{ng} / \mathrm{l} ; \mathrm{p}<0.05$ ) (Table 2, Figure 1A). T2D subjects with $\mathrm{BMI} \geq 30 \mathrm{~kg} / \mathrm{m} 2$ had higher CRP levels (5.2 \pm $4.8 \mathrm{mg} / \mathrm{l}$ vs $3.7 \pm 4.3 \mathrm{mg} / \mathrm{l} ; \mathrm{p}=0.029)$, while those previously treated with metformin had lower levels of IL-6 $(1.51 \pm 3.86 \mathrm{ng} / \mathrm{l}$ vs $2.23 \pm 4.4 \mathrm{ng} / \mathrm{l} ; \mathrm{p}=0.046)$. There were no differences between patients treated with or without insulin and between those with or without lipidlowering medication (data not shown). No correlation was found between glycemic control and inflammatory biomarkers.

Table 3 and Figure $1 \mathrm{~B}$ show clinical characteristics and inflammatory biomarkers of a subgroup of T2D patients before and after glycemic optimization. After a follow-up of 3 months, HbA1c decreased from $9.5 \pm$ $1.8 \%$ to $7.4 \pm 0.8 \%$, without changes in body weight. Improvement of glycemic control was associated with a significant reduction of TGF- $\beta_{1}(41.86 \pm 32.84 \mathrm{ng} / \mathrm{l}$ vs $26.64 \pm 26.91 \mathrm{ng} / \mathrm{l} ; \mathrm{p}=0.02)$. However, changes in TGF$\beta_{1}$ levels did not correlate with those observed in HbA1c.

\section{Discussion}

The present study confirms the low grade systemic inflammation status in T2D patients which is related to features of the metabolic syndrome. However, the main and novel findings are related to increased levels of TGF- $\beta_{1}$ concentration in patients with LDL phenotype $\mathrm{B}$, compared to those with phenotype $\mathrm{A}$, and its

Table 2 Inflammation parameters of control subjects and patients with type 2 diabetes mellitus, according LDL subfraction phenotype, at baseline: T2D: type 2 diabetes

\begin{tabular}{|c|c|c|c|c|}
\hline & $\mathrm{T} 2 \mathrm{D}(\mathrm{N}=122)$ & T2D phenotype $A(N=77)$ & T2D phenotype $B(N=45)$ & Control group $(\mathrm{N}=54)$ \\
\hline C-reactive protein (mg/l) & $4.49 \pm 4.67^{a}$ & $4.31 \pm 4.52$ & $4.86 \pm 5.10$ & $2.38 \pm 3.30$ \\
\hline Interleukin-6 (ng/l) & $1.84 \pm 3.99$ & $2.24 \pm 4.95$ & $1.17 \pm 0.83$ & $1.25 \pm 1.05$ \\
\hline Interleukin-8 (ng/l) & $15.91 \pm 12.85$ & $17.46 \pm 13.74$ & $13.20 \pm 10.87$ & $12.58 \pm 9.29$ \\
\hline Transforming growth factor $\beta 1$ (ng/l) & $41.19 \pm 30.08$ & $31.35 \pm 33.74$ & $53.92 \pm 52.82^{b}$ & $39.55 \pm 42.86$ \\
\hline Monocyte chemotactic protein 1 (ng/l) & $198.0 \pm 132.9^{a}$ & $190.6 \pm 125.6$ & $212.1 \pm 146.21$ & $154.3 \pm 83.0$ \\
\hline Leptin (ng/l) & $8980 \pm 8194$ & $9066 \pm 8786$ & $8787 \pm 7184$ & $7819 \pm 5866$ \\
\hline Adiponectin (ng/l) & $3272.0 \pm 2671^{a}$ & $3663 \pm 3044$ & $2723 \pm 1776^{b}$ & $5369 \pm 3297$ \\
\hline
\end{tabular}

Data are expressed mean \pm SD.

${ }^{\mathrm{a}}, \mathrm{P}<0.05$ vs control group; ${ }^{\mathrm{b}}, \mathrm{P}<0.05$ vs phenotype A patients. 


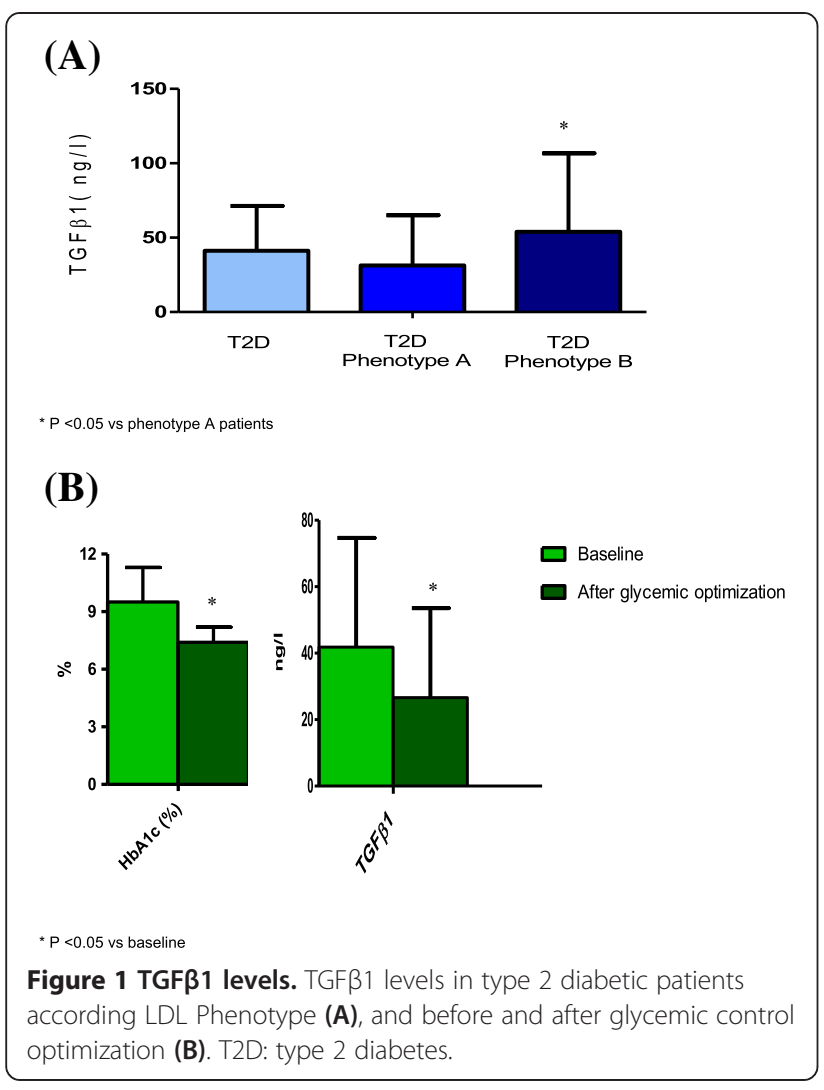

reduction after a marked improvement of glycemic control. These findings suggest that TGF- $\beta_{1}$ may be a link to glycemic control and atherogenic dyslipidemia with the development of diabetic nephropathy.

\section{Systemic inflammation status in T2D subjects}

The analysis of inflammatory parameters showed that plasma concentrations of CRP and MCP1 were higher and that of adiponectin was lower in T2D patients than in control subjects. This observation indicates a greater global systemic inflammation status in diabetic patients, which has been previously suggested that may reflect the activity of the underlying atherosclerotic process [24], and it is concordant with several cross-sectional studies which have shown an increase of CRP levels in patients with diabetes [25-27]. Although the results reported in the literature on the association between IL- 6 and T2D are contradictory $[26,28,29]$, the absence of statistical differences in IL- 6 and other inflammatory parameters could be related to the fact that most patients were treated with medications such as metformin, antihypertensive agents and lipid-lowering drugs, which have demonstrated a beneficial effect on inflammation [12-14]. In addition, the available information about the relationship between inflammatory biomarkers and the characteristics of the diabetes is limited. Some studies have demonstrated significant correlation between CRP levels with features of the metabolic syndrome, including adiposity, hyperinsulinemia, insulin resistance, hypertriglyceridemia and low HDLc $[9,30]$. The preponderance of small LDL particles (LDL phenotype B) is a component of atherogenic dyslipidemia. In accordance, we have observed that obese T2D subjects have higher CRP concentrations and inflammatory status was more unfavorable in patients with LDL phenotype $B$, who had higher concentration of TGF- $\beta_{1}$ and lower of adiponectin than patients with phenotype A. To our knowledge, no other studies have examined this association, but there are some publications agreeing that serum levels of TGF- $\beta_{1}$ are higher in patients with metabolic syndrome than those without it [31] and that oxidized low-density lipoprotein, which is increased in subjects with LDL phenotype $B$, is associated with TGF- $\beta_{1}$ in T2D subjects [32]. Finally, TGF $\beta$ family members have been involved in vascular remodeling defects in experimental models [33], which could contribute to explain the worse prognostic of atherosclerotic cardiovascular disease in diabetic patients.

\section{The effect of improving glycemic control on markers of inflammation in T2D}

It has been shown that in the individuals with impaired glucose tolerance [34] the low-grade chronic inflammation is related to glucose metabolic disturbance and a growing body of evidence supports the hypothesis that chronic systemic inflammation contributes to decrease insulin sensitivity [35]. Moreover, hyperglycemia is a significant stressor that has also been shown to cause chronic inflammation [36]. However, the relationship between inflammatory markers and glycemic control is still not fully understood. In our study, no inflammation marker correlated with $\mathrm{HbA} 1 \mathrm{c}$ levels. These results are consistent with the findings of previous cross-sectional studies which have found an inconsistent association between inflammation and blood glucose levels [16-18], possibly due to previous treatment with metformin, statins and antihypertensive agents, which may limit the power to detect an association between $\mathrm{HbA1c}$ and inflammatory markers. In the longitudinal study, we demonstrated for the first time that improvement of glycemic control by different therapeutic strategies can lower TGF- $\beta_{1}$ concentrations. These results are consistent with the findings in diabetic rats treated with insulin and with the increased expression of TGF- $\beta_{1}$ receptor in the diabetic kidney and in mesangial cells cultured in high glucose $[37,38]$. The lack of significant correlation between the magnitude of the reductions in HbA1c and TGF- $\beta_{1}$ after glycemic optimization may reflect differences in the relative importance of the local versus systemic blood glucose levels, and it does not preclude an underlying relationship between these two parameters. 
Table 3 Clinical characteristics and inflammation parameters of patients with type 2 diabetes mellitus before and after glycemic optimization $(n=42)$

\begin{tabular}{lcc}
\hline & Baseline & $\begin{array}{c}\text { After glycemic } \\
\text { optimization }\end{array}$ \\
\hline Male/female & $27 / 15$ & - \\
Age (years) & $61 \pm 12$ & - \\
Diabetes duration (years) & $37 \pm 14$ & - \\
Chronic complications: & & \\
$\quad$ • Retinopathy (\%) & 59 & - \\
$\quad$ • Nephropathy (\%) & 51.3 & - \\
$\quad$ • Coronary Heart Disease (\%) & 17.9 & - \\
Insulin use (\%) & 75 & 85.7 \\
Cholesterol lowering medication (\%) & 59.5 & 59.5 \\
Weight (kg) & $80.35 \pm 19.52$ & $80.02 \pm 19.71$ \\
Body mass index (Kg/m2) & $29.0 \pm 5.8$ & $28.8 \pm 6$ \\
HbA1c (\%) & $9.5 \pm 1.8$ & $7.4 \pm 0.8^{*}$ \\
C-reactive protein (mg/l) & $3.20 \pm 2.86$ & $3.15 \pm 3.26$ \\
Interleukin-6 (ng/l) & $1.49 \pm 1.12$ & $1.29 \pm 0.70$ \\
Interleukin-8 (ng/l) & $12.84 \pm 7.57$ & $13.82 \pm 10.35$ \\
Transforming growth factor $\beta 1$ (ng/l) & $41.86 \pm 32.84$ & $26.64 \pm 26.91^{*}$ \\
Monocyte chemotactic protein 1 (ng/l) & $224.31 \pm 76.03$ & $227.48 \pm 132.79$ \\
Leptin (ng/l) & $7594 \pm 8852$ & $7817 \pm 7295$ \\
Adiponectin (ng/l) & $3673 \pm 3455$ & $4084 \pm 3927$ \\
\hline Data are expesse mean \pm SD. & &
\end{tabular}

Data are expressed mean \pm SD.

${ }^{*} p<0.05$ vs baseline.

The lack of change in CRP and other inflammatory markers in our study cannot be attributed to weight gain or pharmacological therapy, and confirms the results in the few studies which have evaluated the effect of improving glycemic control on markers of inflammation in type 1 diabetes (DCCT) and T2D [19,20]. In the DCCT study, intensive glycemic control was not associated with changes in levels of CRP and among intensively treated subjects who gained the most weight, there was a significant rise. In T2D, in a study of 18 patients who had been hospitalized to initiate insulin therapy because of poor diabetes control, CRP values, but not MCP1 and fibrinogen levels, were decreased 2 weeks after initiation of insulin therapy. This effect could result from antiinflammatory effects of insulin [18], although these findings were not confirmed in the study of Pradhan et al. [19]. They found that, in patients with recent-onset T2D, treatment during 14 weeks with insulin glargine or metformin compared with placebo did not reduce CRP, IL-6 and soluble tumor necrosis factor receptor 2, despite improving glucose control. In the present study, the duration of the study was sufficient on the basis of assessment of glycemic control by HbA1c, and a marked improvement of glycemic control was obtained, being nearly normal in most of the patients without changes in body weight. Furthermore, lipid-lowering and antihypertensive therapy was unchanged and in most patients insulin therapy was the strategy used to improve glycemic control.

\section{The possible role of TGF- $\beta_{1}$ in diabetic nephropathy}

The critical role of hyperglycemia in the genesis of diabetic nephropathy has been established by cell culture studies, experimental animal models, and clinical trials. Certain cytokines have been identified as likely mediators of the effects of high ambient glucose on the kidney. TGF- $\beta_{1}$, a known pro-fibrotic factor, activates the production of extracellular matrix by mesangial cells and interstitial fibroblasts in the kidneys, and thus contributes to the manifestation of diabetic kidney disease through a number of key pathological events leading to reduced glomerular filtration and impaired renal function $[39,40]$. In mesangial cells, it has been demonstrated that the expression and activity of TGF- $\beta_{1}$ are directly influenced by glucose levels [38]. Moreover, atherogenic dyslipidemia is associated with the onset and progression of nephropathy in T2D subjects, by a mechanism not fully understood $[41,42]$. Therefore, the finding of a higher concentration of TGF- $\beta_{1}$ in patients with atherogenic dyslipidemia provides a potential explanation.

In conclusion, the present study confirms that low-grade chronic inflammation in T2D is related to LDL phenotype B and obesity. In addition, our data demonstrates that improvement of glycemic control reduces TGF- $\beta_{1}$ levels, through an unknown mechanism. These findings might support the role of TGF- $\beta_{1}$ as a likely mediator of the effects of high ambient glucose on the kidney and the beneficial effects of strict glucose control on the development of diabetic nephropathy. However, future studies in larger groups of patients should be performed to confirm these findings.

\section{Abbreviations}

T2D: Type 2 diabetes mellitus; CRP: C-reactive protein; IL-6: Interleukin-6; TNF: Tumor necrosis factor; MCP1: Chemotactic monocyte protein 1; LPPLA2: Lipoprotein-associated phospholipase A2; LDLc: Low density lipoproteins cholesterol; HDLc: High density lipoproteins cholesterol; HbA1C: Glycated haemoglobin; TGF- $\beta_{1}$ : Transforming growth factor or tumor growth factor $\beta_{1}$; BMl: Body mass index.

\section{Competing interests}

The authors declare that they have no competing interests.

\section{Authors' contributions}

IV selected patients, performed statistical analysis and wrote the manuscript. JLS-Q conceived of the study, researched data and reviewed the manuscript. JS-H performed statistical analysis and reviewed the manuscript. DS researched data. JO-L participated in the design of the study, contributed to the discussion and reviewed/edited the manuscript. ADL participated in the design of the study, contributed to the discussion and reviewed/edited the manuscript. AP conceived of the study, selected patients and wrote the manuscript. All authors read and approved the final manuscript. 


\section{Acknowledgements}

This work was supported by grants from Spanish Ministry of Health (ISCIII/ FIS) PI05/2099, PI05/1540, PI06/0500, and PI10/00265. JLS-Q is supported by ISCIII/FIS CP06/0220. JLS-Q and JO-L are members of the Quality Research Group 2009-SGR-1205 from Generalitat de Catalunya. AP and ADL are members of the Quality Research Group 2009-SGR-806 from Generalitat de Catalunya. J.S-H, D.S. and A.P. are members of CIBER de Diabetes y Enfermedades Metabólicas Asociadas (CIBERDEM) from ISCIII. JLS-Q and JO-L are members of the Cardiovascular Research Network (RIC, RD12/0042/0043) from ISCIII. The authors are grateful to Melissa Vance for editorial assistance.

\section{Author details}

'Endocrinology and Nutrition Department, Hospital de la Santa Creu i Sant Pau, C/ Mas Casanovas 90, Barcelona 08025, Spain. ${ }^{2}$ Universitat Autònoma de Barcelona, Barcelona, Spain. ${ }^{3}$ Cardiovascular Biochemistry, Biomedical Research Institute IIB Sant Pau, Barcelona, Spain. ${ }^{4} \mathrm{CIBER}$ of Diabetes and Metabolic Diseases (CIBERDEM), Barcelona, Spain. ${ }^{5}$ Biochemistry Department, Hospital de la Santa Creu i Sant Pau, Barcelona, Spain. ${ }^{6}$ Biochemistry and Molecular Biology Department, Universitat Autònoma de Barcelona, Barcelona, Spain. ${ }^{7}$ CIBER of Biomedicine, Biotechnology and Nanomedicine (CIBERBBN), Barcelona, Spain.

Received: 9 January 2014 Accepted: 3 February 2014

Published: 4 February 2014

\section{References}

1. Eschwege E: The dysmetabolic syndrome, insulin resistance and increased cardiovascular (CV) morbidity and mortality in type 2 diabetes: aetiological factors in the development of CV complications. Diabetes Metab 2003, 29(4 Pt 2):6S19-6S27.

2. Pickup JC, Chusney GD, Thomas SM, Burt D: Plasma interleukin-6, tumour necrosis factor alpha and blood cytokine production in type 2 diabetes. Life Sci 2000, 67(3):291-300.

3. Mirza S, Hossain M, Mathews C, Martinez P, Pino P, Gay JL, Rentfro A McCormick JB, Fisher-Hoch SP: Type 2-diabetes is associated with elevated levels of TNF-alpha, IL-6 and adiponectin and low levels of leptin in a population of Mexican Americans: a cross-sectional study. Cytokine+ 2012, 57(1):136-142.

4. Azar ST, Salti I, Zantout MS, Major S: Alterations in plasma transforming growth factor beta in normoalbuminuric type 1 and type 2 diabetic patients. J Clin Endocrinol Metab 2000, 85(12):4680-4682.

5. Piemonti L, Calori G, Mercalli A, Lattuada G, Monti P, Garancini MP, Costantino F, Ruotolo G, Luzi L, Perseghin G: Fasting plasma leptin, tumor necrosis factor-alpha receptor 2 , and monocyte chemoattracting protein 1 concentration in a population of glucose-tolerant and glucoseintolerant women: impact on cardiovascular mortality. Diabetes Care 2003, 26(10):2883-2889.

6. Sell H, Eckel J: Monocyte chemotactic protein-1 and its role in insulin resistance. Curr Opin Lipidol 2007, 18(3):258-262.

7. Serban M, Tanaseanu C, Kosaka T, Vidulescu C, Stoian I, Marta DS, Tanaseanu S, Moldoveanu E: Significance of platelet-activating factor acetylhydrolase in patients with non-insulin-dependent (type 2) diabetes mellitus. J Cell Mol Med 2002, 6(4):643-647.

8. Calle MC, Fernandez ML: Inflammation and type 2 diabetes. Diabetes Metab 2012, 38(3):183-91.

9. Festa A, D'Agostino R Jr, Howard G, Mykkanen L, Tracy RP, Haffner SM: Chronic subclinical inflammation as part of the insulin resistance syndrome: the Insulin Resistance Atherosclerosis Study (IRAS). Circulation 2000, 102(1):42-47.

10. Lee CC, Adler Al, Sandhu MS, Sharp SJ, Forouhi NG, Erqou S, Luben R, Bingham S, Khaw KT, Wareham NJ: Association of C-reactive protein with type 2 diabetes: prospective analysis and meta-analysis. Diabetologia 2009, 52(6):1040-1047

11. Nakano S, Kuboki K, Matsumoto T, Nishimura C, Yoshino G: Small, dense LDL and high-sensitivity C-reactive protein (hs-CRP) in metabolic syndrome with type 2 diabetes mellitus. J Atheroscler Thromb 2010, 17(4):410-415.

12. Suzuki H, Sakamoto M, Hayashi T, luchi H, Ohashi K, Isaka T, Sakamoto N, Kayama Y, Tojo K, Yoshimura M, Utsunomiya K: Effects of co-administration of candesartan with pioglitazone on inflammatory parameters in hypertensive patients with type 2 diabetes mellitus: a preliminary report. Cardiovasc Diabetol 2013, 12:71
13. Tan KC, Chow WS, Tam SC, Ai VH, Lam CH, Lam KS: Atorvastatin lowers C-reactive protein and improves endothelium-dependent vasodilation in type 2 diabetes mellitus. J Clin Endocrinol Metab 2002, 87(2):563-568.

14. Wagner AM, Sanchez-Quesada JL, Benitez S, Bancells C, Ordonez-Llanos J, Perez A: Effect of statin and fibrate treatment on inflammation in type 2 diabetes. A randomized, cross-over study. Diabetes Res Clin Pract 2011, 93(1):e25-e28.

15. Belalcazar LM: A 1-year lifestyle intervention for weight loss in individuals with type 2 diabetes reduces high C-reactive protein levels and identifies metabolic predictors of change: from the Look AHEAD (Action for Health in Diabetes) study. Diabetes Care 2010, 33(11):2297-303.

16. Leinonen E, Hurt-Camejo E, Wiklund O, Hulten LM, Hiukka A, Taskinen MR: Insulin resistance and adiposity correlate with acute-phase reaction and soluble cell adhesion molecules in type 2 diabetes. Atherosclerosis 2003, 166(2):387-394.

17. Rodriguez-Moran M, Guerrero-Romero F: Increased levels of C-reactive protein in noncontrolled type II diabetic subjects. J Diabetes Complications 1999, 13(4):211-215.

18. Pickup JC, Mattock MB, Crook MA, Chusney GD, Burt D, Fitzgerald AP. Serum sialic acid concentration and coronary heart disease in NIDDM. Diabetes Care 1995, 18(8):1100-1103.

19. Pradhan AD, Everett BM, Cook NR, Rifai N, Ridker PM: Effects of initiating insulin and metformin on glycemic control and inflammatory biomarkers among patients with type 2 diabetes: the LANCET randomized trial. JAMA 2009, 302(11):1186-1194.

20. Takebayashi K, Aso Y, Inukai T: Initiation of insulin therapy reduces serum concentrations of high-sensitivity C-reactive protein in patients with type 2 diabetes. Methods 2004, 53(6):693-699.

21. Sanchez-Quesada JL, Vinagre I, Juan-Franco E, Sanchez-Hernandez J, BlancoVaca F, Ordonez-Llanos J, Perez A: Effect of improving glycemic control in patients with type 2 diabetes mellitus on low-density lipoprotein size, electronegative low-density lipoprotein and lipoprotein-associated phospholipase A2 distribution. Am J Cardiol 2012, 110(1):67-71.

22. Sanchez-Quesada JL, Vinagre I, de Juan-Franco E, Sanchez-Hernandez J, Bonet-Marques R, Blanco-Vaca F, Ordonez-Llanos J, Perez A: Impact of the LDL subfraction phenotype on Lp-PLA2 distribution, LDL modification and HDL composition in type 2 diabetes. Cardiovasc Diabetol 2013, 12:112.

23. Sanchez-Quesada JL, Benitez S, Otal C, Franco M, Blanco-Vaca F, OrdonezLlanos J: Density distribution of electronegative LDL in normolipemic and hyperlipemic subjects. J Lipid Res 2002, 43(5):699-705.

24. Baars T, Konorza T, Kahlert P, Mohlenkamp S, Erbel R, Heusch G, Kleinbongard $P$ : Coronary aspirate TNFalpha reflects saphenous vein bypass graft restenosis risk in diabetic patients. Cardiovasc Diabetol 2013, 12:12.

25. Wannamethee SG, Lowe GD, Rumley A, Cherry L, Whincup PH, Sattar N: Adipokines and risk of type 2 diabetes in older men. Diabetes Care 2007, 30(5):1200-1205.

26. Wang X, Bao W, Liu J, Ouyang YY, Wang D, Rong S, Xiao X, Shan ZL, Zhang Y, Yao P, Liu LG: Inflammatory Markers and Risk of Type 2 Diabetes: A systematic review and meta-analysis. Diabetes Care 2013, 36(1):166-175.

27. Festa A, D'Agostino R Jr, Tracy RP, Haffner SM: Elevated levels of acutephase proteins and plasminogen activator inhibitor-1 predict the development of type 2 diabetes: the insulin resistance atherosclerosis study. Diabetes 2002, 51(4):1131-1137.

28. Bertoni AG, Burke GL, Owusu JA, Carnethon MR, Vaidya D, Barr RG, Jenny NS, Ouyang P, Rotter Jl: Inflammation and the incidence of type 2 diabetes: the Multi-Ethnic Study of Atherosclerosis (MESA). Diabetes Care 2010, 33(4):804-810.

29. Krakoff J, Funahashi T, Stehouwer CD, Schalkwijk CG, Tanaka S, Matsuzawa Y, Kobes S, Tataranni PA, Hanson RL, Knowler WC, Lindsay RS: Inflammatory markers, adiponectin, and risk of type 2 diabetes in the Pima Indian. Diabetes Care 2003, 26(6):1745-1751.

30. Yudkin JS, Stehouwer CD, Emeis JJ, Coppack SW: C-reactive protein in healthy subjects: associations with obesity, insulin resistance, and endothelial dysfunction: a potential role for cytokines originating from adipose tissue? Arterioscler, Thromb, Vasc Biol 1999, 19(4):972-978.

31. Sciarretta S, Ferrucci A, Ciavarella GM, De PP, Venturelli V, Tocci G, De BL, Rubattu S, Volpe M: Markers of inflammation and fibrosis are related to cardiovascular damage in hypertensive patients with metabolic syndrome. Am J Hypertens 2007, 20(7):784-791. 
32. Nakhjavani M, Esteghamati A, Asgarani F, Khalilzadeh O, Nikzamir A, Safari R: Association of oxidized low-density lipoprotein and transforming growth factor-beta in type 2 diabetic patients: a cross-sectional study. Trans/ Res 2009, 153(2):86-90.

33. Di BE, Campagnolo P, Margariti A, Zampetaki A, Karamariti E, Hu Y, Xu Q: Endothelial lineage differentiation from induced pluripotent stem cells is regulated by microRNA-21 and transforming growth factor beta2 (TGF-beta2) pathways. J Biol Chem 2013 [Epub ahead of print].

34. Muller S, Martin S, Koenig W, Hanifi-Moghaddam P, Rathmann W, Haastert B, Giani G, Illig T, Thorand B, Kolb H: Impaired glucose tolerance is associated with increased serum concentrations of interleukin 6 and co-regulated acute-phase proteins but not TNF-alpha or its receptors. Diabetologia 2002, 45(6):805-812.

35. Pickup JC: Inflammation and activated innate immunity in the pathogenesis of type 2 diabetes. Diabetes Care 2004, 27(3):813-823.

36. Astrup A, Finer N: Redefining type 2 diabetes: 'diabesity' or 'obesity dependent diabetes mellitus'? Obes Rev 2000, 1(2):57-59.

37. Isono M, Mogyorosi A, Han DC, Hoffman BB, Ziyadeh FN: Stimulation of TGF-beta type II receptor by high glucose in mouse mesangial cells and in diabetic kidney. Am J Physiol Renal Physiol 2000, 278(5):F830-F838.

38. Koppel H, Riedl E, Braunagel M, Sauerhoefer S, Ehnert S, Godoy P, Sternik P, Dooley S, Yard BA: L-carnosine inhibits high-glucose-mediated matrix accumulation in human mesangial cells by interfering with TGF-beta production and signalling. Nephrol Dial Transplant 2011, 26(12):3852-3858.

39. Lim AK, Tesch GH: Inflammation in diabetic nephropathy. Mediators Inflamm 2012, 2012:146154.

40. Loeffler I, Wolf G: Transforming growth factor-beta and the progression of renal disease. Nephrol Dial Transplant 2013, 2013:2013.

41. Caramori ML, Fioretto P, Mauer M: The need for early predictors of diabetic nephropathy risk: is albumin excretion rate sufficient? Diabetes 2000, 49(9):1399-1408.

42. Muntner P, Coresh J, Smith JC, Eckfeldt J, Klag MJ: Plasma lipids and risk of developing renal dysfunction: the atherosclerosis risk in communities study. Kidney Int 2000, 58(1):293-301.

doi:10.1186/1475-2840-13-34

Cite this article as: Vinagre et al:: Inflammatory biomarkers in type 2

diabetic patients: effect of glycemic control and impact of Idl subfraction phenotype. Cardiovascular Diabetology 2014 13:34.

\section{Submit your next manuscript to BioMed Central and take full advantage of:}

- Convenient online submission

- Thorough peer review

- No space constraints or color figure charges

- Immediate publication on acceptance

- Inclusion in PubMed, CAS, Scopus and Google Scholar

- Research which is freely available for redistribution 